Published in "Applied Clay Science 82(): 16-23, 2014"

which should be cited to refer to this work.

\title{
Pottery kiln and drying oven from Aventicum (2nd century AD, Ct. Vaud, Switzerland): Raw materials and temperature distribution
}

\author{
Giacomo Eramo $^{\mathrm{a}, *}$, Marino Maggetti ${ }^{\mathrm{b}, 1}$ \\ a Dipartimento di Scienze della Terra e Geoambientali, Università degli Studi di Bari “A. Moro”, Via E. Orabona 4, I-70125 Bari, Italy \\ ${ }^{\mathrm{b}}$ Department of Geosciences, University of Fribourg, Chemin du Musée 6, CH-1700 Fribourg, Switzerland
}

\begin{abstract}
Fireboxes of two pottery structures, excavated in 2002 at Aventicum (at present Avenches), the capital of Roman Switzerland, were studied to understand their function in the artisan quarter. Twenty-one oriented samples underwent petrographical, mineralogical and chemical analyses to determine the nature of the raw materials and the temperature distribution.

Both structures are typologically different and show differing degrees of thermal impacts. Inferred maximum temperatures for kiln Structure 6, as deduced from phase associations, were as high as $1050-1200{ }^{\circ} \mathrm{C}$. Such high temperatures are typically recorded in fireboxes of ceramic kilns. Structure 180 is proposed to have been a drying oven, as evidenced by: (1) its phase associations, pointing to maximum firing temperatures of c. $950-1050{ }^{\circ} \mathrm{C}$, and (2) its unusual shape. Six out of seven clays from the artisan quarter revealed Ca-rich composition, but the Ca-poor one was preferentially used by Roman potters for bricks and clay binders to build the two structures. Such "refractory" clays are obviously better suited to withstand higher firing temperatures and for a longer period than Ca-rich clays.
\end{abstract}

\section{Introduction}

Aventicum was the most important site of Roman Helvetia. In this town (Fig. 1), as well as in other Roman sites in Switzerland, local production of pottery and tiles is evidenced by kiln structures (Le Ny, 1988). Archaeological excavations in the vicinity of the town showed remains of potter's workshops in two intramuros zones (Sur Saint-Martin and Faubourgs Nord-Est) and one extramuros (En Chaplix) (Castella, 1995; Eschbach and Castella, 1995; Morel et al., 2002) (Fig. 2). Circular or rectangular (in plan) firebox bases are what remains of the kilns. Although this typological variability was not strictly related to the kind of ceramic fired (Peacock, 1982), circular kilns were normally for pots and rectangular for bricks (Castella, 1995).

Archaeometrical studies on workshop wasters of Terra Sigillata (TS) and common ware from Aventicum indicated that both Ca-rich and Ca-poor clays were used (Jornet, 1982; Zanco, 1999).

Archaeological excavations in the northeastern part of Aventicum (a la montagne) during the years 2001-2002 by the Archaeological Survey of Canton Vaud brought to light portions of a necropolis (1st century A.D.) and an artisan quarter (second half of the 1st century). In the

\footnotetext{
* Corresponding author. Tel.: + 39080544 2608; fax: + 390805442625 E-mail addresses: giacomo.eramo@geomin.uniba.it (G. Eramo), marino.maggetti@unifr.ch (M. Maggetti).

${ }^{1}$ Tel.: + 410263008930 .
}

latter, remains of two pottery structures, a pile of pottery waste and a well were found (Fig. 3). Both structures show different shapes, states of conservation and partially preserved fireboxes (Fig. 4). The firebox of Structure 6 (240 cm long, $60 \mathrm{~cm}$ wide) is preserved only for the first $60 \mathrm{~cm}$ in height and is divided into a praefurnium and combustion chamber (Fig. 4a). It was built in an elongated pit with unfired clay bricks. The space between the sidewalls and the surface of the pit was filled with clay. Bottom and inner walls are made of previously unfired, red bricks. On both sidewalls, six air ducts occur, separated by four arch shoulders supporting the perforated floor of the rectangular firing chamber. Kiln Structure 6 belongs to type II/b in the classification of Cuomo di Caprio (1972), which considers the overall shape of structure and the arrangement of the firebox. Roman Gaul kilns were classified by Duhamel (1974), taking into account the number of chambers, the type of air draught and the number of fireboxes. Kiln types II/b or II/c would then be possible, since the duct type is not clearly determined.

The remains of Structure 180 consist of the bottom of the firebox with the first $15 \mathrm{~cm}$ of the sidewalls $(\sim 200 \times 50 \mathrm{~cm})$. The inner wall and bottom are made of hardened clay. This structure was also dug into an elongated pit. Some fragments of roof tiles occur close to the long sides. Several stone fragments are placed just next to the mouth of the firebox. The shape of this structure does not match any of the structures in the classification of Cuomo di Caprio (1972) and Duhamel (1974) and could well be a drying oven as reported by Peacock (1982) from other pottery workshops. This interpretation is supported by similarity of the structure with "T"-shaped drying ovens from Britain (Young, 1977). 


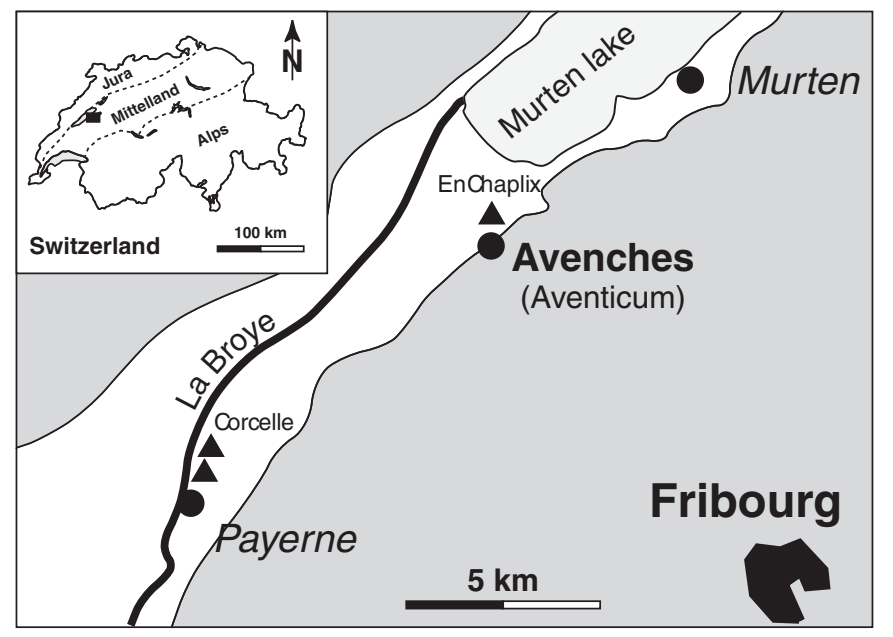

$\square$ Moraine and alluvial deposits (Quaternary) $\square$ Molasse (Tertiary)

\section{- Local clays (Jornet, 1982)}

Fig. 1. Position of Aventicum and of the clay samples (Jornet, 1982).

Several kilns were found in Aventicum, but no archaeometrical analyses were undertaken before now. A petrographical, mineralogical and chemical study of fragments from both pottery structures and local clays was therefore made in order to verify their compatibility and to compare them with published reference groups of local pottery (Jornet, 1982; Zanco, 1999). Additionally, firebox temperatures were inferred from a phase analysis of oriented samples.

\section{Location and geological aspects}

Roman Aventicum is about $15 \mathrm{~km}$ NW of Fribourg, next to the boundary between the Jura and the Mittelland (Fig. 1). It lies on the southern flank of the Broye valley, a few kilometres from the Lake of Murten. Würm moraine deposit as well as post-glacial lacustrine deposits crop out in this area. The Tertiary basement contains marls and sandstones of the Lower Fresh Water Molasse (Aquitanian). The Murten Lake represents the last stage in the migration of a former Mega-lake since Post-Würm, due to environmental evolution

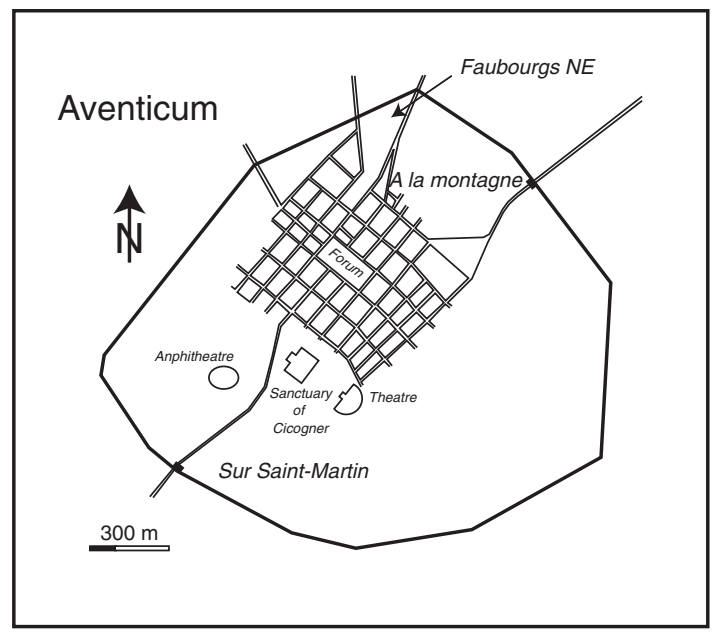

Fig. 2. Roman Aventicum with the location of main archaeological structures and the excavated areas quoted in this study.
(Rumeau, 1954; Sieber, 1959). Such lacustrine deposits are a few metres thick and alternate between non calcareous sandy clays with marly clays and sand lenses. Sigg et al. (1986) report conspicuous mineralogical and geochemical heterogeneities, both vertically and laterally, of these lacustrine clays of Corcelle, near Payerne (Fig. 1), mainly due to varying contents of carbonates. A low content of carbonates was instead detected in the lacustrine deposits of En Chaplix, about $2 \mathrm{~km}$ north of Aventicum, which were exploited for tile production in the early part of last century (Letsch et al., 1907). The compositional variability of the lacustrine deposits made available different kinds of clay in the Broye valley, and still exploited as raw materials for tiles and bricks.

\section{Sampling}

Structure 6: samples were collected from the W sidewall, from the backside and from the floor of the firebox (Fig. 4a). Structure 180: samples were collected from the lower portion of the sidewalls and from the floor of the firebox (Fig. 4b). Clays: the locations of the clay samples collected in the substratum of both structures are shown in Fig. 3. Archaeological and lithological features are presented in Table 1.

\section{Analytical methods}

All the petrographical, mineralogical and chemical analyses were performed in the laboratories of the Department of Geosciences at the University of Fribourg $(\mathrm{CH})$.

\subsection{Petrographical analysis by optical microscopy}

Petrographic analyses were carried out on thin sections from bricks AV59, 61, 63 and 66 of Structure 6, and AV55 and 56 of Structure 180. AV63a corresponds to the inside of the brick, AV63b to the part exposed to the flame. Modal percentages of non-plastic inclusions were estimated by visual comparison with reference chart (Matthew et al., 1991).

\subsection{Mineralogical analysis by X-ray diffraction (XRD)}

Between 5 and $10 \mathrm{~g}$ of the samples were powdered with a tungsten carbide (WC) mill. After milling, a fraction of the clay samples (AV44-50) with grain size $<4 \mu \mathrm{m}$ was separated by settling in water under gravity (Stokes' law). These samples were analysed by X-ray diffraction (XRD) on a Philips PW1800 diffractometer with $\mathrm{Cu}-\mathrm{K}_{\alpha}$ radiation at $40 \mathrm{kV}$ and $40 \mathrm{~mA}$ (step angle of $0.02^{\circ} 2 \theta$ from $2^{\circ}$ to $65^{\circ}$, measuring time $1 \mathrm{~s}$ per step). The clay samples (AV44-50) in the fraction $<4 \mu \mathrm{m}$ were subjected to heat treatment at $550{ }^{\circ} \mathrm{C}$ for $1 \mathrm{~h}$ to discriminate between chlorite and kaolinite (Brindley and Brown, 1980).

\subsection{Chemical analysis by X-ray fluorescence (XRF)}

Bulk chemical analyses were performed on glass tablets using a PHILIPS PW 2400 X-ray fluorescence spectrometer equipped with a rhodium X-ray tube. Loss on ignition was determined by calcination, heating $2 \mathrm{~g}$ of sample at $1000{ }^{\circ} \mathrm{C}$ for $1 \mathrm{~h}$. The glass tablets were obtained by fusion of $0.700 \mathrm{~g}$ of calcined sample powder with $0.350 \mathrm{~g}$ of $\mathrm{LiF}$ and $6.650 \mathrm{~g}$ of $\mathrm{B}_{4} \mathrm{Li}_{2} \mathrm{O}_{7}$ in a Pt crucible $\left(\mathrm{T}=1150{ }^{\circ} \mathrm{C}\right.$; $\mathrm{t}=10 \mathrm{~min}$ ), followed by analysing using a PHILIPS PERL'X-2 machine. Detection limit for major elements was 0.01 mass\% and for trace elements 1-5 ppm. 


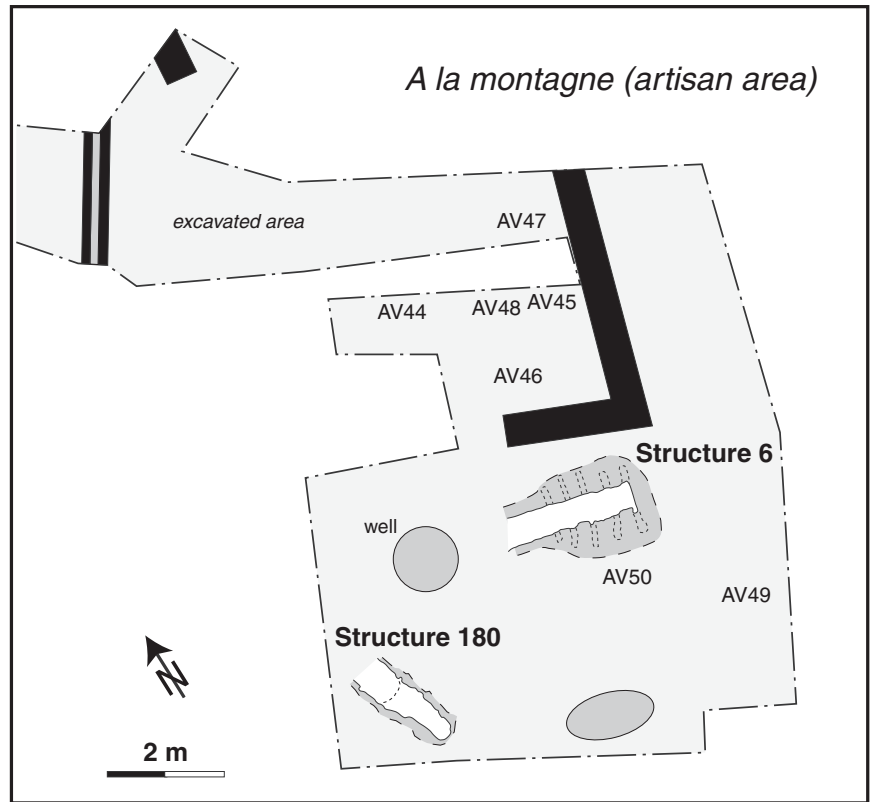

Fig. 3. A portion of the area excavated in the 2002 (a la montagne) and the position of the two pottery structures (Structure 6, Structure 180). AV44-50: clay samples collected in the excavated area.

\section{Results}

An overview of the samples' location in the archaeological context, the texture and the colour, was given in Table 1, whilst the results of bulk chemical analysis were presented in Table 2. In Table 3, the eight mineral assemblages detected by XRD in the furnace fragments and in

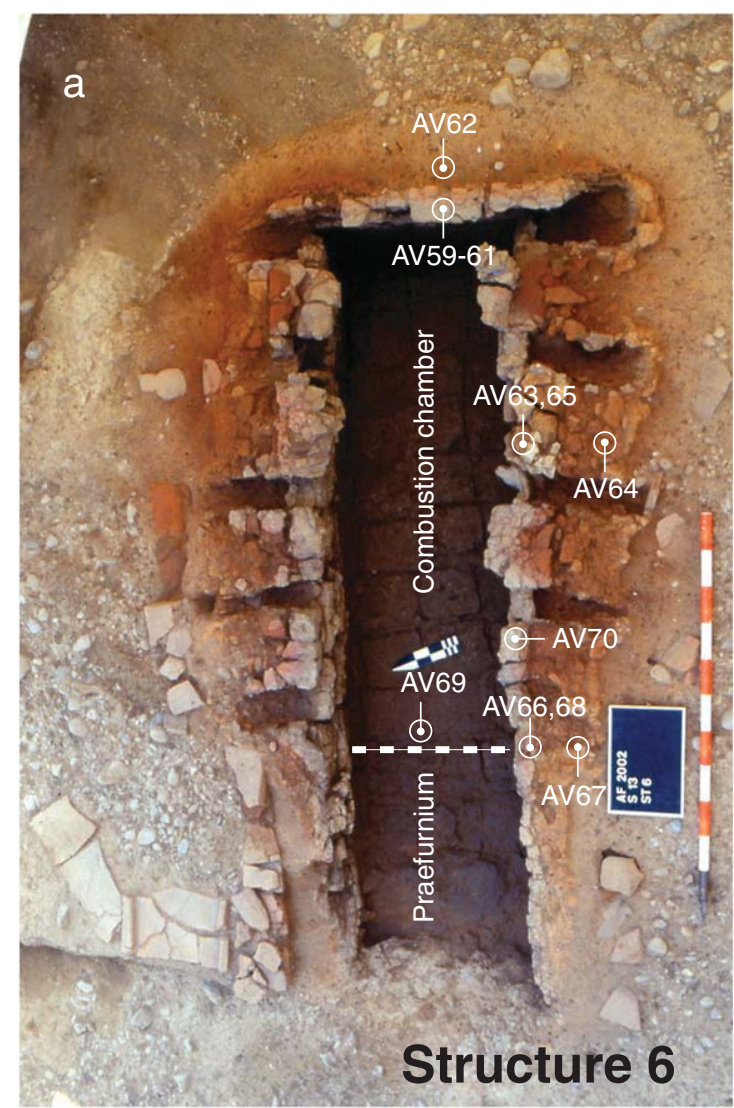

the clay samples collected in the excavation area were reported. From mineral assemblage $\mathrm{A}$ to $\mathrm{H}$ the maximum temperature range is progressively higher. Mineral assemblages F, G and $\mathrm{H}$ show phases which form by reducing conditions, such as hercynite and magnetite. The colours of these samples are from deep brown to black. When the principal peaks of kaolinite and chlorite were observed, the sample did not exceeded $500{ }^{\circ} \mathrm{C}$ (mineral assemblages A and B). These samples exposed to temperatures below $500{ }^{\circ} \mathrm{C}$ show colours ranging between yellowish and brown. In the case of assemblage $\mathrm{C}$, maximum temperatures between $500{ }^{\circ} \mathrm{C}$ and $750{ }^{\circ} \mathrm{C}$ were estimated, since kaolinite peaks and (002) peak of chlorite were absent, whilst calcite peaks were still present. Colours from grey to orange were observed in samples with mineral assemblage $C$, whereas the vitrified samples of mineral assemblages $\mathrm{D}, \mathrm{F}$ and $\mathrm{H}$ are dark grey. The temperature range between $750{ }^{\circ} \mathrm{C}$ and $950{ }^{\circ} \mathrm{C}$ (D) was defined because of the absence of chlorite and calcite peaks and the residual presence of (110) peak of illite/muscovite. The complete absence of illite/muscovite peaks and occurrence of hematite's ones allow inference of maximum temperatures above $950{ }^{\circ} \mathrm{C}$ for the assemblage E. The same was supposed for assemblage $\mathrm{G}$, which features magnetite instead of hematite. Some hercynite coexisting with hematite was detected in the samples of assemblage $\mathrm{F}$. Together with the absence of illite/muscovite, a temperature range between $950{ }^{\circ} \mathrm{C}$ and $1050{ }^{\circ} \mathrm{C}$ is indicated for this assemblage (Eramo, 2005; Letsch and Noll, 1983). The highest temperature range was estimated for assemblage $\mathrm{H}$ because of the presence of cristobalite. Due to the presence of hercynite and the absence of mullite this mineral assemblage formed at temperatures between $1050{ }^{\circ} \mathrm{C}$ and $1200{ }^{\circ} \mathrm{C}$ (Heimann et al., 1980; Richardson and Rigby, 1949).

\subsection{Structure 6}

Microscope examination of four bricks revealed big pores with a complex border geometry and frequently elongated shape (max. $7 \mathrm{~mm}$

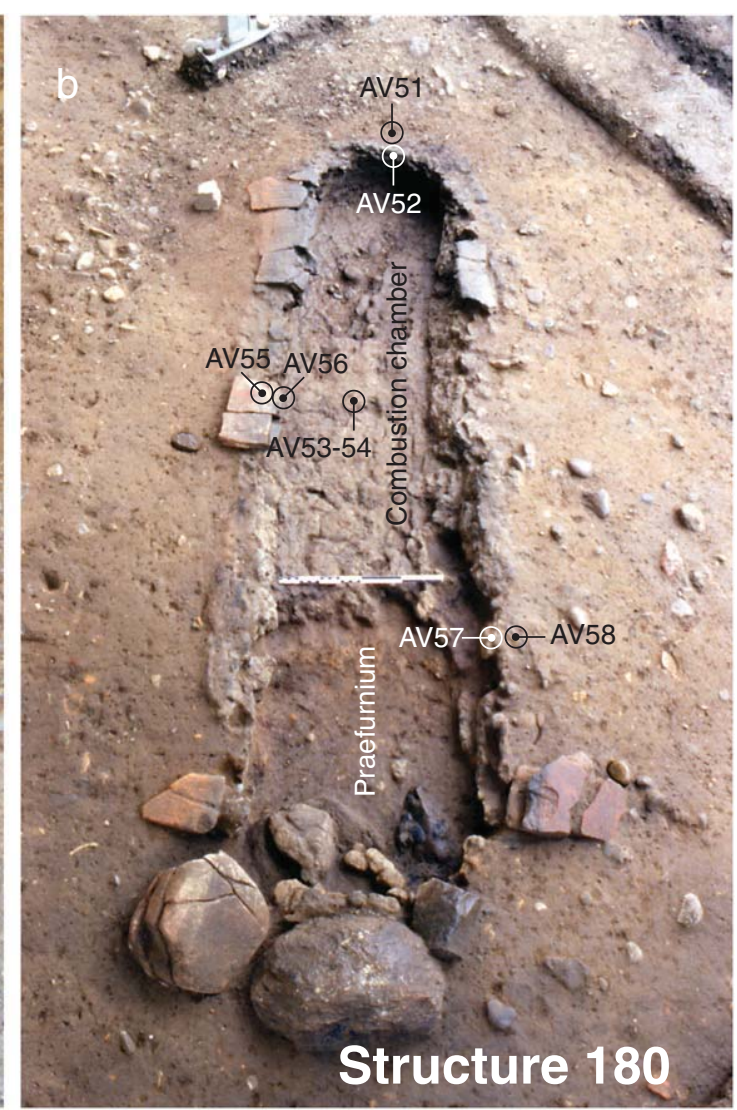

Fig. 4. Pottery structures Structure 6 and Structure 180 and the position of the analysed samples. Each structure distinguished the praefurnium from the combustion chamber. 
Table 1

Samples from Aventicum

\begin{tabular}{|c|c|c|c|c|c|c|}
\hline Sample & Position & Description & Colour & Texture & Mineral assemblage & Notes \\
\hline \multicolumn{7}{|c|}{ Clay samples from the excavation area } \\
\hline AV44 & & Clay & Yellowish & Clayey sand & A & \\
\hline AV45 & & Clay & Brown & Clayey sand & A & \\
\hline AV46 & & Clay & Brown & Sandy clay & A & \\
\hline AV47 & & Clay & Brown & Sandy clay & A & \\
\hline AV48 & & Clay & Yellowish & Sandy clay & A & \\
\hline AV49 & & Clay & Yellowish & Clayey sand & A & \\
\hline AV50 & & Clay & Yellowish & Clayey sand & B & \\
\hline \multicolumn{7}{|c|}{ Structure 180} \\
\hline AV51 & Wall S-side SE & Back-wall clay filler & Brown & Clayey sand & A & \\
\hline AV52 & Wall S-side NW & Back-wall clay filler & Greyish & Clayey sand + pebbles & A & \\
\hline AV53 & Bottom of the kiln (surface) & Floor of the fire box & Greyish & Clayey sand + pebbles & $\mathrm{C}$ & \\
\hline AV54 & Bottom of the kiln (beneath the surface) & Floor of the fire box & Brown & Clayey sand + pebbles & A & \\
\hline AV55 & Wall E-top SW & Tile & D. grey-orange & Clayey sand & $\mathrm{E}$ & \\
\hline AV56 & Wall E-side W & Binder & D. grey-orange & Clayey sand & $\mathrm{F}$ & Vitrification \\
\hline AV57 & Wall W-top SE & Back-wall clay filler & Grey-brown & Clayey sand + pebbles & B & \\
\hline AV58 & Wall W-bottom NW & Back-wall clay filler & Grey-yellow & Clayey sand + pebbles & $\mathrm{B}$ & \\
\hline \multicolumn{7}{|c|}{ Structure 6} \\
\hline AV59 & Wall E-top NW & Brick & Black-violet-red-orange & Clayey sand + pb & $\mathrm{F}$ & Vitrification \\
\hline AV60 & Wall E-side SW & Binder & Orange & Clayey sand + pebbles & $\mathrm{B}$ & \\
\hline AV61 & Wall E-side NW & Brick & D. grey-orange & Clayey sand + pebbles & $\mathrm{D}$ & Vitrification \\
\hline AV62 & Wall E-side SW & Back-wall clay filler & Yellow-orange & Clayey sand + pebbles & A & \\
\hline AV63a & Wall S-top SE & Brick & Red-orange & Clayey Sand + pebbles & $\mathrm{E}$ & \\
\hline AV63b & Wall S-top SE & Brick & Black & Clayey sand + pebbles & $\mathrm{H}$ & Vitrification \\
\hline AV64 & Wall S-side SE & Back-wall clay filler & Orange & Clayey sand & B & \\
\hline AV65 & Wall S-side NE & Brick & Black-ocher & Clayey sand + pebbles & $\mathrm{D}$ & Vitrification \\
\hline AV66 & Wall S-top SE & Brick & Black-ocher & Clayey sand & $\mathrm{D}$ & Vitrification \\
\hline AV67 & Wall S-side NW & Back-wall clay filler & Orange & Clayey sand & C & \\
\hline AV68 & Wall S-side NW & Binder & Ocher & Clayey sand & $\mathrm{D}$ & \\
\hline AV69 & Bottom of the firebox & Brick & Ocher-orange & Clayey sand + pebbles & A & \\
\hline AV70 & Wall S-side NW & Brick & Grey-ocher & Clayey sand & G & \\
\hline
\end{tabular}

in length), originated by both paste manipulation and combustion of vegetal inclusions during firing/use. Paste's matrix shows low birefringence colours and paste's non-plastic inclusions (NPIs) show a seriate texture (Fig. 5). Grain sizes are mostly fine sand (125-250 $\mu \mathrm{m})$, with maximum grain diameter not exceeding $2.5 \mathrm{~mm}$. NPIs about $20 \mathrm{vol} . \%$ were estimated. Monocrystalline quartz is more abundant than polycrystalline, K-feldspar and plagioclase show variable amounts, white micas (in AV63b and 66 with altered optical features) are rare, as well as altered carbonatic clasts $(0.5-2 \mathrm{~mm})$. The bulk chemical composition is quite homogeneous (Table 2), with generally low $\mathrm{CaO}$ (1-3 wt.\%), except for AV62 (6.77 wt.\%). The mineral assemblages (A-H) determined by XRD in the samples of Structure 6 show significant differences (Tables 1 and 3). Calcite was detected in AV62, 67 and 69 (A and C). Sheet silicates such as kaolinite, chlorite and illite/muscovite were detected in AV61 and 66 (D), but not in AV59 (F), 63a (E) and 63b (H) (Table 3). The latter contain some cristobalite. Hercynite is also present in AV59 and 63b and magnetite in AV70 (G). Some verification was observed on samples directly exposed to the flame in the firebox, characterised by such high temperature mineral assemblages as D, $\mathrm{F}$ and $\mathrm{H}$.

\subsection{Structure 180}

Only two samples were analysed in thin section (AV55 and AV56). Tile AV55 has a deep grey (plane light) matrix on the side exposed to the flames and a red-brown on the opposite. Their NPIs' texture is seriate, with angular to subangular grains (Fig. 6). Prevalent grain sizes are between 125 and $250 \mu \mathrm{m}$ (fine sand) with diameters of max. $0.9 \mathrm{~mm}$. Mineralogically, NPIs (estimated 30 vol.\%) consist of abundant monocrystalline and some polycrystalline quartz, potassium feldspar, plagiocalse and white mica. The latter has grain sizes ranging from 10 to $20 \mu \mathrm{m}$, with larger grains oriented parallel to the surface of the tile. Micas show altered optical features such as earthy aspect in plane light and medium-low birefringence. In addition, ferruginous aggregates with silt grains are dispersed in a Fe-rich matrix.

Binder AV56 has a heterogeneous three zone-structure. The matrix is homogeneously grey in plane light, but with a birefringence changing from low to none in the three zones. The zone with a direct fire contact is vitrified along a length about $1 \mathrm{~cm}$. Relict quartz, altered feldspars and opaque aggregate can be recognised in a glassy matrix. About 50 vol.\% of this zone consists of rounded pores (diam. $1-4 \mathrm{~mm}$ ). Porosity is strongly reduced about 10 vol.\% in the next, second zone. The silty matrix can easily be identified under the microscope. Porosity of the third zone increases about 20 vol.\%, and the matrix shows low birefringence.

XRD patterns are characterised by abundant quartz, with minor calcite in AV51, 52 and 54, which is absent in the other samples. Plagioclase and potassium feldspar occur in each sample in variable amounts. Kaolinite, illite/muscovite and chlorite peaks were detected in all spectra, with the exceptions of AV55 and 56. Hematite occurs in AV55, and hercynite with cristobalite in AV56 (Table 3). The chemical composition is highly variable, as exemplified by $\mathrm{SiO}_{2}$ and $\mathrm{CaO}$ (Table 2).

\subsection{Clay samples}

Quartz is the main phase in the XRD spectra, with calcite in varying amounts and subordinate plagioclase and potassium feldspar. Kaolinite and illite/muscovite were detected in the oriented sample of the fraction $<4 \mu \mathrm{m}$. Heat treatment of these fractions confirmed the occurrence of chlorite. The samples are all $\mathrm{Ca}$-rich, with $\mathrm{Fe}_{2} \mathrm{O}_{3 \text { tot }}$ below 5 wt.\%.

\section{Discussion}

\subsection{Raw materials: provenance}

Both pottery structures were made with Ca-poor raw materials, except AV62 (one out of 13 samples) in Structure 6 and AV51, 52 
Table 2

XRF data of the kiln fragments and of the clays from Avenches. (Oxides and LOI in wt.\%, elements in ppm).

\begin{tabular}{|c|c|c|c|c|c|c|c|c|c|c|c|c|c|c|c|c|c|c|c|c|c|c|c|}
\hline Sample & $\mathrm{SiO}_{2}$ & $\mathrm{TiO}_{2}$ & $\mathrm{Al}_{2} \mathrm{O}_{3}$ & $\mathrm{Fe}_{2} \mathrm{O}_{3 \text { tot }}$ & $\mathrm{MnO}$ & $\mathrm{MgO}$ & $\mathrm{CaO}$ & $\mathrm{Na}_{2} \mathrm{O}$ & $\mathrm{K}_{2} \mathrm{O}$ & $\mathrm{P}_{2} \mathrm{O}_{5}$ & Total & LOI & $\mathrm{Ba}$ & $\mathrm{Cr}$ & $\mathrm{Cu}$ & $\mathrm{Nb}$ & $\mathrm{Ni}$ & $\mathrm{Pb}$ & $\mathrm{Rb}$ & $\mathrm{Sr}$ & $\mathrm{Y}$ & $\mathrm{Zn}$ & $\mathrm{Zr}$ \\
\hline \multicolumn{24}{|c|}{ Clay samples from the excavation area } \\
\hline AV44 & 59.10 & 0.51 & 10.74 & 3.59 & 0.09 & 1.99 & 20.41 & 1.02 & 2.01 & 0.25 & 99.87 & 15.64 & 365 & 114 & 20 & 12 & 61 & 19 & 89 & 501 & 24 & 61 & 166 \\
\hline AV45 & 62.71 & 0.50 & 11.76 & 4.18 & 0.11 & 1.82 & 14.43 & 1.30 & 2.31 & 0.45 & 99.69 & 12.16 & 351 & 99 & 18 & 11 & 58 & 19 & 108 & 261 & 27 & 69 & 150 \\
\hline AV46 & 63.91 & 0.54 & 12.37 & 4.47 & 0.12 & 1.86 & 12.43 & 1.32 & 2.43 & 0.34 & 99.92 & 11.22 & 363 & 116 & 39 & 12 & 174 & 21 & 111 & 237 & 29 & 72 & 153 \\
\hline AV47 & 63.78 & 0.63 & 14.16 & 4.71 & 0.08 & 2.06 & 9.99 & 1.14 & 2.40 & 0.66 & 99.73 & 10.02 & 367 & 126 & 23 & 14 & 72 & 29 & 117 & 210 & 30 & 86 & 153 \\
\hline AV48 & 51.85 & 0.55 & 13.21 & 5.16 & 0.12 & 2.99 & 22.15 & 1.23 & 2.37 & 0.27 & 100.04 & 17.53 & 353 & 114 & 18 & 12 & 70 & 22 & 110 & 372 & 27 & 83 & 106 \\
\hline AV49 & 50.58 & 0.35 & 7.96 & 4.33 & 0.09 & 1.30 & 31.94 & 1.09 & 1.55 & 0.26 & 99.56 & 22.63 & 407 & 80 & 12 & 8 & 32 & 12 & 59 & 311 & 21 & 30 & 174 \\
\hline AV50 & 75.50 & 0.46 & 11.69 & 3.44 & 0.09 & 1.32 & 2.76 & 1.91 & 2.46 & 0.29 & 100.03 & 3.77 & 380 & 92 & 13 & 10 & 44 & 25 & 106 & 114 & 27 & 53 & 185 \\
\hline \multicolumn{24}{|c|}{ Structure 180} \\
\hline AV51 & 66.87 & 0.40 & 10.83 & 3.02 & 0.07 & 1.41 & 13.16 & 1.59 & 2.33 & 0.14 & 99.93 & 10.65 & 412 & 85 & 14 & 9 & 41 & 20 & 99 & 261 & 23 & 52 & 143 \\
\hline AV52 & 67.76 & 0.36 & 10.05 & 2.60 & 0.07 & 1.21 & 13.43 & 1.60 & 2.22 & 0.17 & 99.57 & 11.12 & 345 & 76 & 12 & 9 & 36 & 15 & 99 & 279 & 20 & 46 & 138 \\
\hline AV53 & 82.37 & 0.40 & 9.55 & 2.34 & 0.05 & 0.71 & 0.80 & 1.69 & 1.92 & 0.11 & 100.04 & 11.62 & 369 & 86 & 7 & 11 & 28 & 15 & 83 & 95 & 20 & 38 & 230 \\
\hline AV54 & 67.91 & 0.34 & 9.37 & 2.79 & 0.08 & 1.21 & 14.58 & 1.60 & 1.96 & 0.15 & 100.12 & 2.51 & 360 & 73 & 24 & 7 & 38 & 18 & 92 & 329 & 22 & 46 & 130 \\
\hline AV55 & 67.58 & 0.69 & 16.35 & 5.72 & 0.13 & 2.42 & 1.03 & 1.92 & 3.52 & 0.10 & 99.60 & 2.24 & 462 & 98 & 20 & 17 & 62 & 30 & 156 & 93 & 32 & 93 & 207 \\
\hline AV56 & 77.20 & 0.47 & 12.00 & 3.49 & 0.09 & 1.27 & 0.93 & 1.95 & 2.69 & 0.13 & 100.34 & 2.69 & 362 & 91 & 17 & 12 & 43 & 9 & 117 & 88 & 24 & 51 & 199 \\
\hline AV57 & 81.97 & 0.38 & 9.30 & 2.45 & 0.09 & 0.75 & 1.12 & 1.74 & 2.09 & 0.13 & 100.12 & 6.50 & 343 & 90 & 15 & 9 & 30 & 18 & 95 & 89 & 21 & 44 & 191 \\
\hline AV58 & 81.05 & 0.39 & 9.88 & 2.46 & 0.07 & 0.78 & 0.91 & 1.82 & 2.27 & 0.10 & 99.82 & 2.12 & 365 & 79 & 4 & 10 & 28 & 18 & 96 & 95 & 22 & 43 & 207 \\
\hline \multicolumn{24}{|c|}{ Structure 6} \\
\hline AV59 & 75.48 & 0.50 & 12.23 & 3.68 & 0.10 & 1.43 & 1.27 & 1.94 & 2.83 & 0.16 & 99.72 & 4.09 & 357 & 89 & 18 & 12 & 45 & 19 & 116 & 93 & 31 & 60 & 202 \\
\hline AV60 & 75.30 & 0.49 & 12.28 & 3.75 & 0.11 & 1.34 & 1.74 & 1.94 & 2.56 & 0.15 & 99.78 & 1.52 & 376 & 96 & 16 & 12 & 50 & 16 & 115 & 108 & 29 & 57 & 206 \\
\hline AV61 & 75.53 & 0.49 & 12.11 & 3.64 & 0.10 & 1.40 & 1.52 & 1.88 & 2.83 & 0.15 & 99.75 & 1.38 & 360 & 88 & 19 & 14 & 43 & 22 & 120 & 98 & 29 & 57 & 180 \\
\hline AV62 & 72.42 & 0.40 & 10.63 & 3.12 & 0.09 & 1.28 & 6.77 & 1.93 & 2.29 & 0.34 & 99.38 & 0.63 & 341 & 81 & 27 & 9 & 38 & 18 & 99 & 177 & 28 & 51 & 152 \\
\hline AV63a & 75.56 & 0.48 & 12.01 & 3.62 & 0.11 & 1.42 & 1.38 & 1.90 & 2.79 & 0.17 & 99.55 & 0.34 & 368 & 87 & 13 & 13 & 43 & 23 & 111 & 94 & 26 & 56 & 182 \\
\hline AV63b & 75.95 & 0.49 & 12.13 & 3.63 & 0.10 & 1.37 & 1.24 & 1.85 & 2.86 & 0.15 & 99.86 & 0.39 & 355 & 92 & 23 & 10 & 44 & 18 & 114 & 93 & 27 & 57 & 189 \\
\hline AV64 & 76.60 & 0.46 & 11.81 & 3.44 & 0.10 & 1.26 & 1.44 & 1.98 & 2.54 & 0.36 & 100.10 & 0.51 & 340 & 93 & 14 & 10 & 44 & 15 & 108 & 98 & 30 & 53 & 185 \\
\hline AV65 & 76.04 & 0.48 & 12.05 & 3.58 & 0.10 & 1.38 & 1.36 & 1.81 & 2.97 & 0.18 & 100.06 & 0.61 & 348 & 83 & 42 & 11 & 43 & 31 & 112 & 98 & 29 & 57 & 191 \\
\hline AV66 & 74.24 & 0.47 & 11.68 & 3.46 & 0.10 & 1.40 & 1.57 & 1.64 & 4.75 & 0.20 & 99.60 & 0.56 & 374 & 82 & 16 & 12 & 42 & 20 & 147 & 101 & 25 & 54 & 190 \\
\hline AV67 & 76.17 & 0.43 & 11.26 & 3.26 & 0.10 & 1.20 & 2.76 & 1.92 & 2.58 & 0.19 & 99.98 & 0.79 & 365 & 84 & 17 & 10 & 40 & 18 & 111 & 122 & 27 & 55 & 177 \\
\hline AV68 & 74.83 & 0.48 & 11.97 & 3.54 & 0.10 & 1.54 & 1.46 & 1.82 & 3.87 & 0.19 & 99.92 & 1.50 & 381 & 90 & 12 & 11 & 46 & 21 & 129 & 100 & 29 & 57 & 190 \\
\hline AV69 & 75.78 & 0.44 & 11.67 & 3.38 & 0.10 & 1.34 & 2.03 & 1.97 & 2.71 & 0.15 & 99.67 & 2.66 & 413 & 82 & 21 & 11 & 40 & 16 & 118 & 110 & 30 & 53 & 176 \\
\hline AV70 & 74.98 & 0.48 & 12.04 & 3.56 & 0.10 & 1.42 & 1.23 & 1.84 & 3.58 & 0.17 & 99.50 & 0.58 & 389 & 82 & 14 & 11 & 44 & 23 & 126 & 96 & 28 & 58 & 187 \\
\hline
\end{tabular}

LOI: Loss on ignition $\left(1000{ }^{\circ} \mathrm{C}\right.$ for $\left.1 \mathrm{~h}\right)$.

and 54 (three out of eight samples) in Structure 180 (Fig. 7). This is marked in contrast to the clay samples from the excavation site which are, with one exception, very Ca-rich. Such compositional variability of clay samples in the excavation area agrees with that observed by other authors (Jornet, 1982; Sigg et al., 1986) and demonstrates that clayey layers with different $\mathrm{CaO}$ contents outcrop even in the artisan quarter. All the clay samples are but AV50 Ca-rich, which is compositionally very similar to the Ca-poor bricks of Structure 6. It can therefore be inferred that these bricks were made from this clay type. A local exploitation of Ca-rich clays is corroborated by the fact that samples from the two pottery structures and clays from the excavation area contain mineral assemblage $\mathrm{A}$.

\subsection{Raw materials: Processing}

Local clays (this paper and Jornet, 1982) and structure fragments have marked chemical affinity, differing from the local pottery produced in Aventicum. Ca-poor (Jornet, 1982) and Ca-rich (Zanco,

Table 3

Mineral composition of the kiln fragments and related formation temperatures.

\begin{tabular}{lll}
\hline $\begin{array}{l}\text { Mineral } \\
\text { assemblage }\end{array}$ & Phase content & $\begin{array}{l}\text { Temperature } \\
\text { range }\left(\mathrm{T}^{\circ} \mathrm{C}\right)\end{array}$ \\
\hline $\mathrm{A}$ & $\mathrm{Qtz}+\mathrm{Cal}+\mathrm{Pl}+\mathrm{Kfs}+\mathrm{Chl}+\mathrm{Kln}+\mathrm{Ill} / \mathrm{Ms}$ & $<500$ \\
$\mathrm{~B}$ & $\mathrm{Qtz}+\mathrm{Pl}+\mathrm{Kfs}+\mathrm{Chl}+\mathrm{Kln}+\mathrm{Ill} / \mathrm{Ms}+(\mathrm{Cal})$ & $<500$ \\
$\mathrm{C}$ & $\mathrm{Qtz}+\mathrm{Pl}+\mathrm{Kfs}+\mathrm{Chl}+\mathrm{Ill} / \mathrm{Ms}+(\mathrm{Cal})$ & $500-750$ \\
$\mathrm{D}$ & $\mathrm{Qtz}+\mathrm{Pl}+\mathrm{Kfs}+\mathrm{Ill} / \mathrm{Ms}$ & $750-950$ \\
$\mathrm{E}$ & $\mathrm{Qtz}+\mathrm{Pl}+\mathrm{Kfs}+\mathrm{Hem}$ & $>800$ \\
$\mathrm{~F}$ & $\mathrm{Qtz}+\mathrm{Pl}+\mathrm{Kfs}+\mathrm{Hc}+(\mathrm{Hem})$ & $950-1050$ \\
$\mathrm{G}$ & $\mathrm{Qtz}+\mathrm{Pl}+\mathrm{Kfs}+\mathrm{Mag}$ & $>950$ \\
$\mathrm{H}$ & $\mathrm{Qtz}+\mathrm{Pl}+\mathrm{Kfs}+\mathrm{Hc}+\mathrm{Crs}$ & $1050-1200$ \\
\hline
\end{tabular}

Table key.

Mineral abbreviations after Kretz (1983): Cal = calcite; Chl = chlorite; Crs = cristobalite; Hem = hematite; Hc = hercynite; Ill/Ms = illite/muscovite; Kfs = K-feldspar; Kln = kaolinite; Mag = magnetite; $\mathrm{Pl}=$ plagioclase; $\mathrm{Qtz}=$ quartz.
1999) potteries demonstrate lower $\mathrm{SiO}_{2} / \mathrm{Al}_{2} \mathrm{O}_{3}$ ratios than the structure fragments and the clays of this study (Fig. 7). Such different ratios could be explained by processing of the raw materials in order to produce the tableware, i.e. by the extraction of coarser grains (mainly quartz), as evidenced by the finer granulometry of the tableware (Fig. 8). Ca-contents are not affected by this process, since carbonates are mainly dispersed in the clayey matrix. On the other hand, the fragments of both structures denote a chemical compatibility with the untreated local clays. The seriate grain size distribution of the NPIs in the structure fragments is indicative of their original presence in the raw materials (Maggetti, 1994).

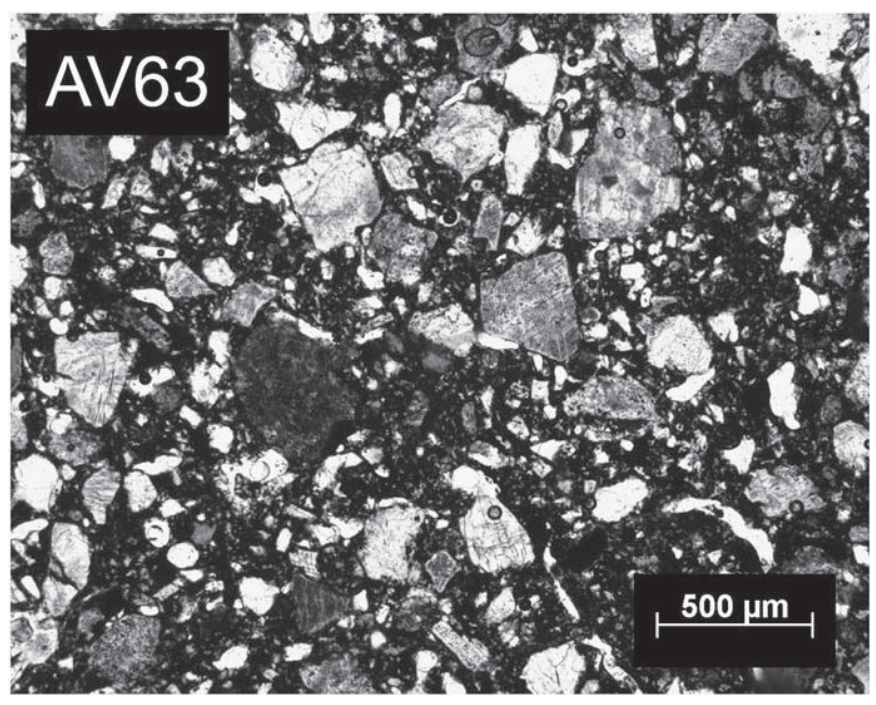

Fig. 5. Photomicrograph of a brick from Structure 6 showing a seriate texture of the non-plastic inclusions with prevalent fine-sand grain size (plane light). 


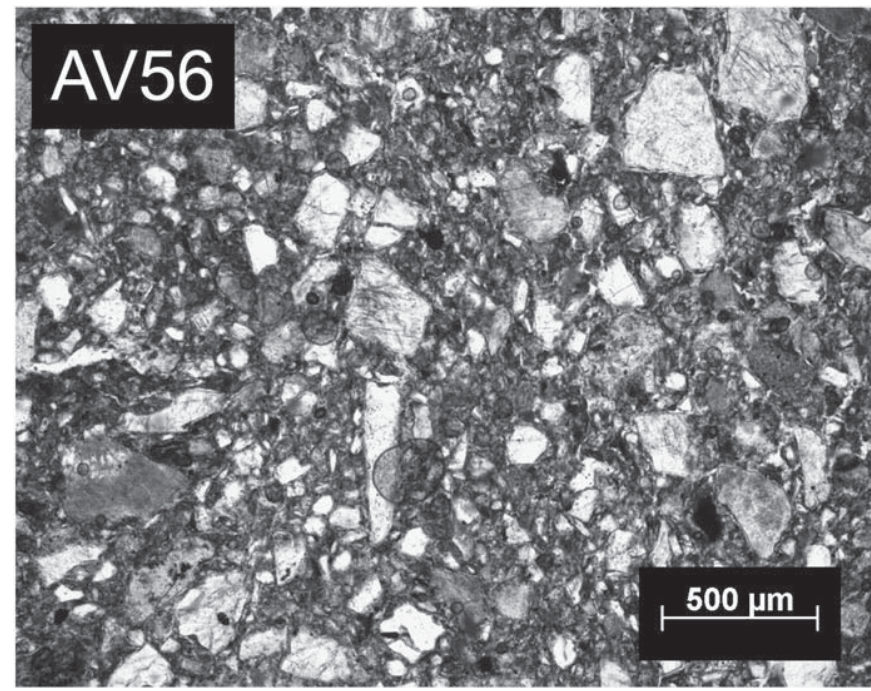

Fig. 6. Photomicrograph of a binder from Structure 180 showing a seriate texture of the non-plastic inclusions with prevalent fine-sand grain size (plane light).

Generally all structure fragments are Ca-poor, as are the bricks (when present) and the clayey binder used for the sidewalls. This denotes an intentional choice of specifically "refractory" clays from the locally available raw material.

As observed in the macroscopic samples, the bricks were tempered with vegetal fragments to reduce shrinkage. This vegetal temper was burnt out during many firing cycles and left elongated relict voids. Such secondary porosity generated during the firing/use of the bricks in the kilns, as well as that induced by coarse NPIs from the use of non elutriated clay, enhanced the thermal insulation of the kiln (Hein and Kilikoglou, 2007; Hein et al., 2008; Tite et al., 2001). Since very few samples of brick show very high sintering (i.e. assemblages $F, G$ and $H$ ), the plastic deformation of the bricks was not caused by intense heat exposure, but was due to water plasticity and indicates that they were used unfired.

\subsection{Temperature distribution}

The maximum firing temperatures estimated for the analysed samples were determined taking into account the thermal stability range of the mineral phases of the ceramic and clay samples as detected by XRD. Firing atmosphere is proposed to be overall oxidising, as evidenced by the red colour of most samples (Table 1). However, magnetite and hercynite bearing samples point to more reducing conditions. The mineral associations detected by XRD were compared with those of a Ca-poor clay collected in proximity of the archaeological site (AV42; Jornet, 1982), experimentally fired in the range 600 to $1100{ }^{\circ} \mathrm{C}$. The experimental firing data obtained by Maggetti and Rossmanith (1981), Maggetti (1982), Letsch and Noll (1983) and Maritan et al. (2006) were taken into account for phases not observed by Jornet (1982) (i.e. kaolinite, cristobalite and hercynite).

The two kilns show different structures and thermal impact as estimated after XRD results (Table 3). It should be considered that the maximum temperatures estimated in the firebox of the two structures are higher than those that effectively occurred in the chamber placed above it, which define the function of the kiln itself. Structure 6 shows firing temperatures increasing from the praefurnium to end of the firebox and from the bottom to the top of the firebox's walls, according to the air draught path (Fig. 4a). AV69, collected from the bottom at the entrance of the firebox was exposed to temperatures lower than $500{ }^{\circ} \mathrm{C}$. The brick fragment AV66 and the sample of clay binder (AV68) in contact with it were also sampled at the entrance of the firebox on the surface of the south wall and record temperatures between $750{ }^{\circ} \mathrm{C}$ and $950{ }^{\circ} \mathrm{C}$. The temperature estimated for the clay used as back-wall filler (AV67) decreases in range between $500{ }^{\circ} \mathrm{C}$ and $750{ }^{\circ} \mathrm{C}$. Temperature estimates for the brick sample AV70, just $30 \mathrm{~cm}$ from AV66 in the firebox, are above $950{ }^{\circ} \mathrm{C}$. Again on the south wall, in the middle of the firebox two fragments of the same brick were analysed, one from the wall surface (AV63b) and

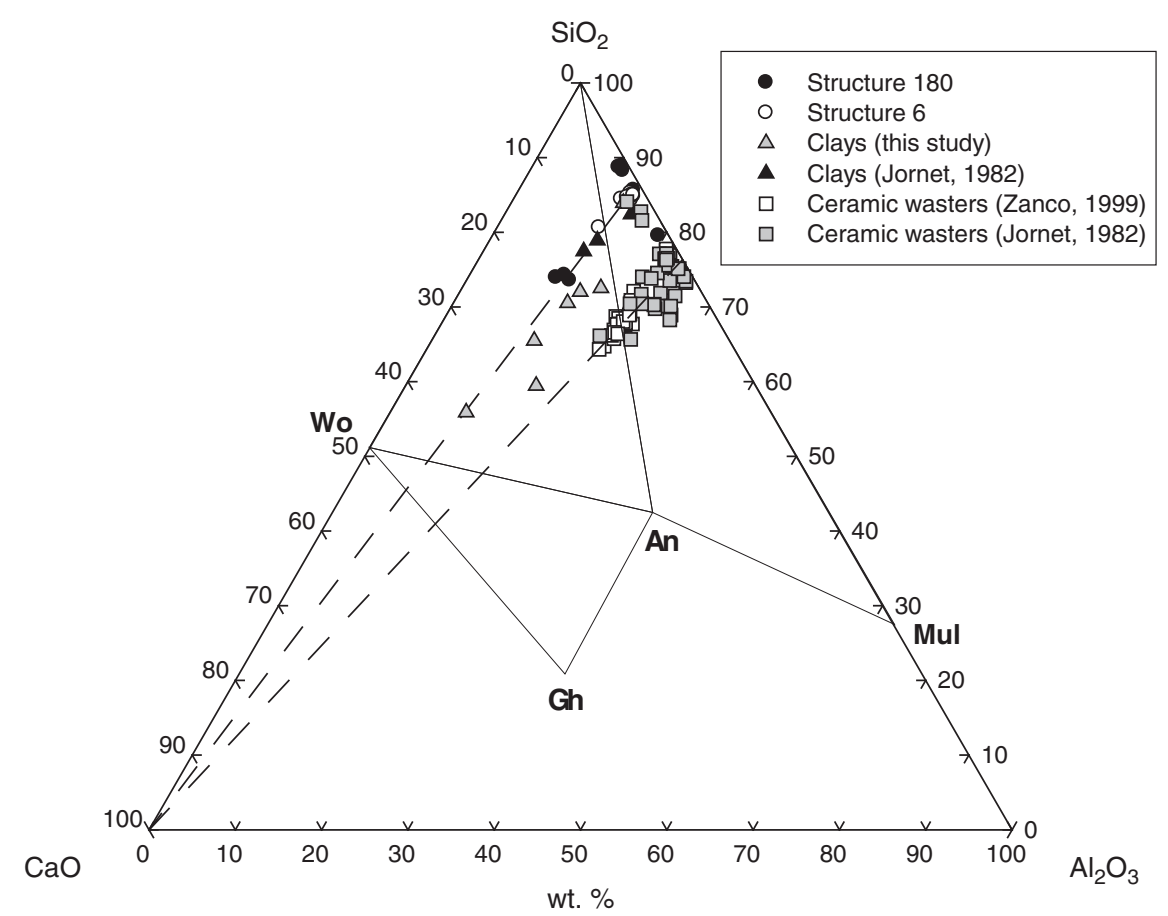

Fig. 7. $\mathrm{SiO}_{2}-\mathrm{CaO}-\mathrm{Al}_{2} \mathrm{O}_{3}$ triangular plot of structure fragments, local clays and ceramic wasters from Aventicum. Mostly all structure fragments are aligned along the upper dashed trend-line, but mostly all ceramic wastes along the lower trend-line. Such different $\mathrm{SiO}_{2} / \mathrm{Al}_{2} \mathrm{O}_{3}$ ratios could be related to a different quartz content in the local clays, the structure fragments and the pottery (here due to clay processing). 

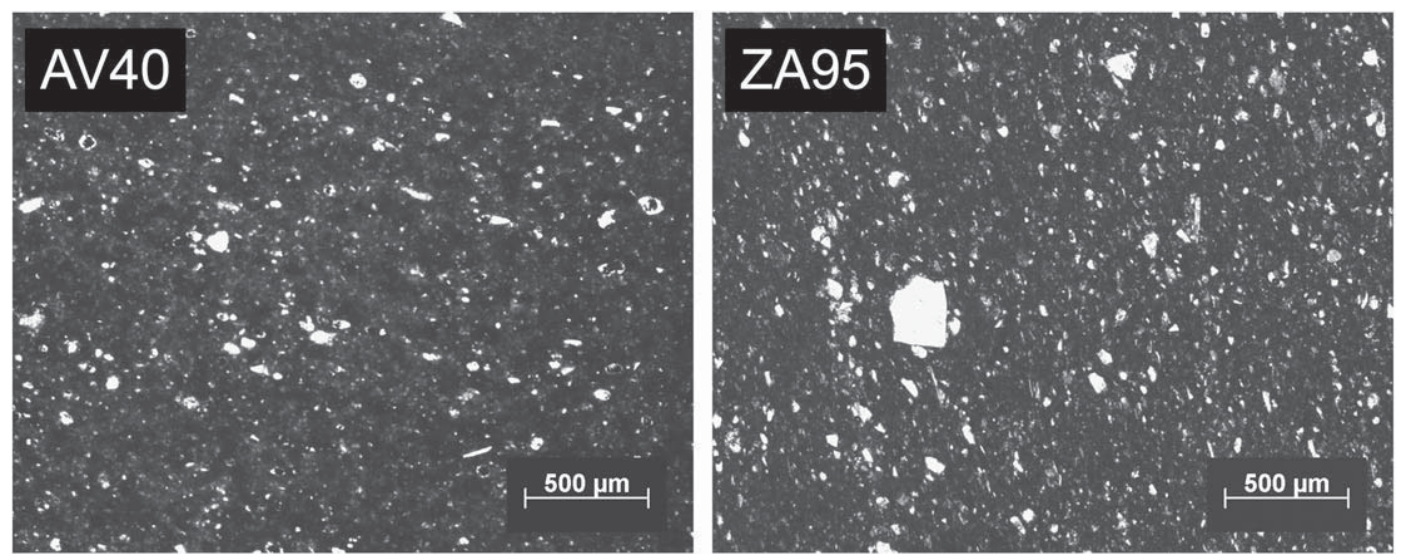

Fig. 8. Microphotographs of a ceramic waster from Sur Saint-Martin (AV40) and Faubourgs NE (ZA95). Plastic inclusions are in the silty grain size dimension. Plane light.

the other (AV63a) from the inside. Maximum temperatures between $1050{ }^{\circ} \mathrm{C}$ and $1200{ }^{\circ} \mathrm{C}$ were estimated for the two fragments, with different firing atmospheres, more reducing for AV63b and more oxidising for AV63a. Another brick fragment (AV65) sampled on the same wall, below the brick AV63, recorded maximum temperatures between $750{ }^{\circ} \mathrm{C}$ and $950{ }^{\circ} \mathrm{C}$. The clay used as back-wall filler (AV64) had a thermal impact below $500{ }^{\circ} \mathrm{C}$. Similar differences among the maximum temperatures were estimated for the brick positioned on the top (AV59) and in the middle (AV61) of the back wall of the firebox, as well as for the clay used as back-wall filler (AV62). The clay binder (AV60) was less exposed to heating than the brick (AV59) to which it was in contact.

Heat-induced transformations are less intense for Structure 180, with samples from the inner surface of the sidewall recording temperatures lower than $500{ }^{\circ} \mathrm{C}$, except AV55 and AV56, which reached temperatures between $950{ }^{\circ} \mathrm{C}$ and $1050{ }^{\circ} \mathrm{C}$. The bottom of the firebox (AV53) recorded temperatures between $500{ }^{\circ} \mathrm{C}$ and $750{ }^{\circ} \mathrm{C}$.

Although the structures of the two kilns are clearly different, a true pyrotechnological correlation cannot be made, since in Structure 180 the walls of the firebox are almost completely absent (Fig. 4b).

\section{Structure 180}
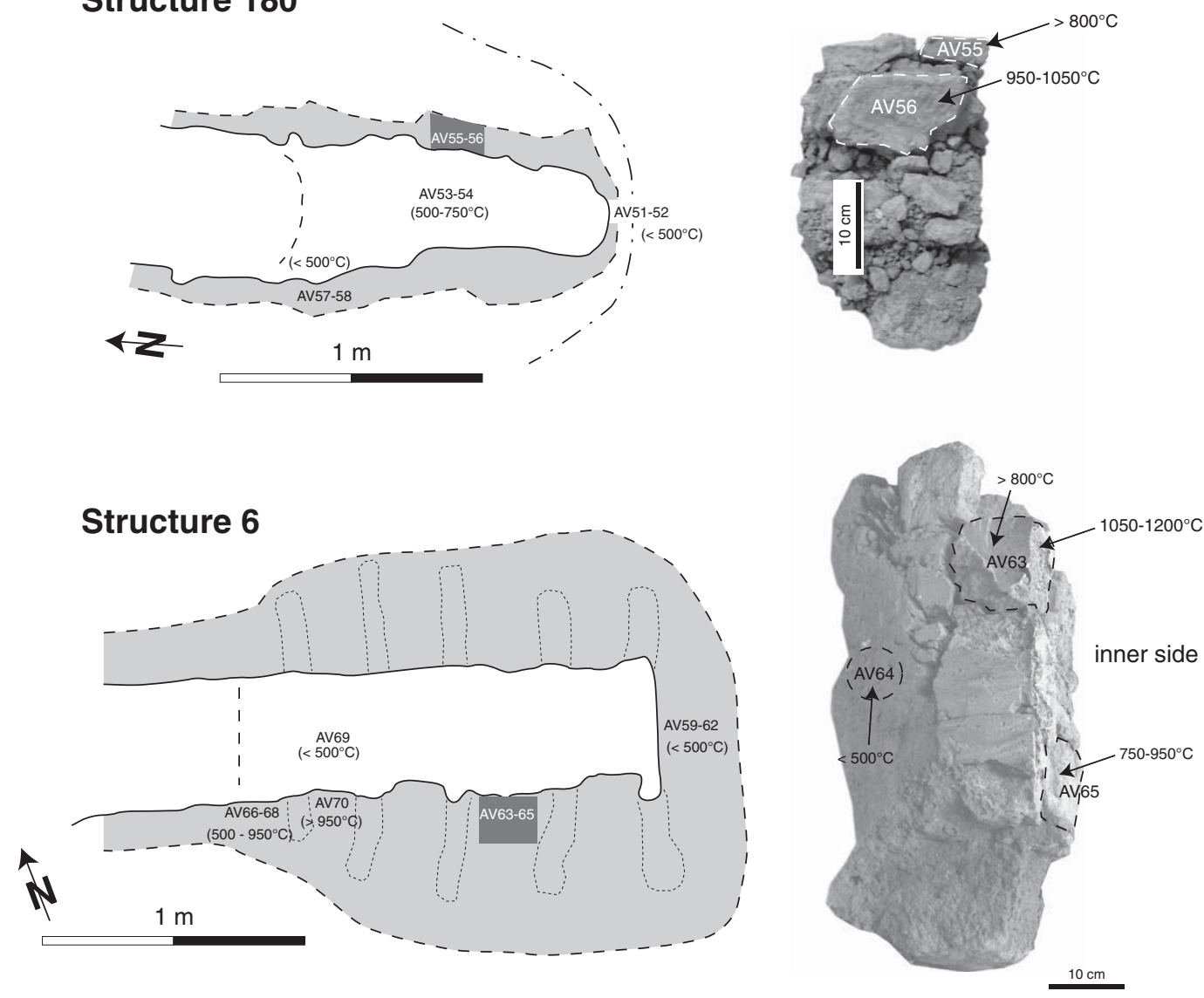

Fig. 9. Schematic view of the structures with the relative temperature ranges estimated for the different samples. Two portions of the wall of the combustion chamber of Structure 6 and Structure 180 are shown, with sample positions and temperatures estimated. 
As seen in Structure 6, the highest temperatures were recorded by the bricks positioned on the top of the firebox walls. Thus relatively higher temperatures are expected in the firebox of Structure 180 as suggested by the samples AV55 and AV56. Fig. 9 illustrates the temperature distribution in the two structures.

\section{Conclusions}

The two kilns studied are typologically and structurally different to one another. One (Structure 6) is a true pottery kiln, built with unfired bricks in a trench dug in the Ca-poor and -rich clayey lacustrine deposits. Roman potters used only the former as raw material for the bricks and the binder. This technological choice was likely motivated by the fact that such clays are better suited to withstand the high temperatures occurring in fire chambers of pottery kilns than the lower melting Ca-rich raw materials. The maximum temperatures on the inner surface of the firebox are estimated between $1050{ }^{\circ} \mathrm{C}$ and $1200{ }^{\circ} \mathrm{C}$. This is consistent with the estimated $\sim 1100{ }^{\circ} \mathrm{C}$ recorded by pottery wasters found in a nearby kiln (zone Sur St. Martin, Jornet, 1982). Comparably high temperatures (above $1050{ }^{\circ} \mathrm{C}$ on the bottom of the fire box) and the use of Ca-poor clays as raw materials for the kiln were also reported by Maggetti (1995) for a Roman pottery kiln.

The shape of Structure 180 is very different from any known pottery kiln structure. The inferred firing temperatures of its firebox are lower (maximum between $950{ }^{\circ} \mathrm{C}$ and $1050{ }^{\circ} \mathrm{C}$ ), although the walls were poorly preserved and further thermal data of the firebox are lacking. The shape and temperatures therefore fit best with a drying oven.

\section{References}

Brindley, G.W., Brown, G., 1980. Crystal structures of clay minerals and their X-ray identification. Mineralogical Society Monograph No. 5, pp. 305-356 (London).

Castella, D., 1995. Potiers et tuiliers à Aventicum. Un état de questions. Bullettin de l'Association Pro Aventico 37, 185-192.

Cuomo di Caprio, N., 1972. Proposta di classificazione delle fornaci per ceramica e laterizi nell'area italiana. Sibrium 11, 371-464.

Duhamel, P., 1974. Les fours de potiers. Les dossiers d'archéologie 6, 54-66.

Eramo, G., 2005. The melting furnace of the Derrière Sairoche glassworks (Court, Swiss Jura): heat-induced mineralogical transformations and their technological signification. Archaeometry 47, 571-592.

Eschbach, F., Castella, D., 1995. L'atelier de tuiliers d'Avenches "En Chaplix". Bullettin de l'Association Pro Aventico 37, 143-188.

Heimann, R.B., Maggetti, M., Einfalt, H., 1980. Zum Verhalten des Eisens beim Brennen eines kalkhaltigen illitischen Tons unter reduzierenden Bedingungen. Berichte der Deutchen Keramischen Gesellschaft 57, 145-152.

Hein, A., Kilikoglou, V., 2007. Modeling of thermal behaviour of ancient metallurgical ceramics. Journal of the American Ceramic Society 90 (3), 878-884.
Hein, A., Müller, N.S., Day, P.M., Kilikoglou, V., 2008. Thermal conductivity of archaeological ceramics: the effect of inclusions, porosity and firing temperature. Thermochimica Acta 480, 35-42.

Jornet, A., 1982. Analyse minéralogique et chmique de la céramique romaine suisse enduit brillant. Unpublished PhD thesis, Institut de Minéralogie et Pétrographie, University of Fribourg.

Kretz, R., 1983. Symbols of rock-forming minerals. American Mineralogist 68, 277-279.

Le Ny, F., 1988. Les fours de tuiliers gallo-romains. Etude technologique, typologique et statistique. Chronologie, Documents d'archéologie française, 12. éditions MSH Paris.

Letsch, J., Noll, W., 1983 . Phase formation in several ceramic subsystems at $600{ }^{\circ} \mathrm{C}-1000^{\circ} \mathrm{C}$ as function of oxygen fugacity. Ceramic Forum International - Berichte der Deutschen Keramischen Gesellschaft 60 (7), 259-267.

Letsch, E, Zschokke, B., Rollier, L, Moser, R, 1907. Die schweizerischen Tonlager. Beiträge zur Geologie der Schweizerisch. Geotechnische Serie, IV Lief.

Maggetti, M., 1982. Phase analysis and its significance for technology and origin. In: Olin, J.S., Franklin, A.D. (Eds.), Archaeological Ceramics. Smithsonian Institution, Washington D.C., pp. 121-133.

Maggetti, M., 1994. Mineralogical and petrographical methods for the study of ancient pottery. In: Burragato, F., Grubessi, O., Lazzarini, L. (Eds.), 1st European Workshop on Archaeological Ceramics 10-12, 1991. Dip. Scienze delle Terra, Università degl Studi di Roma "La Sapienza”, Roma, pp. 23-35.

Maggetti, M., 1995. Technical aspects of the terra sigillata production: the pottery centre of Schwabegg (Augsburg, Germany, 2/3 D C. AD). In: Vincenzini, P. (Ed.) The ceramics Cultural Heritage, Techna - Monographs in Materials and Society, 2, pp. 221-228.

Maggetti, M., Rossmanith, M., 1981. Archaeothermometry of kaolinitc clays. Revue d'Archéometrie 3, 185-194 (Supplement).

Maritan, L., Nodari, L., Mazzoli, C., Milano, A., Russo, U., 2006. Influence of firing conditions on ceramic products: experimental study on clay rich in organic matter. Applied Clay Science 31, 1-15.

Matthew, A.J., Woods, A.J., Oliver, C., 1991. Spots before the eyes: new comparison charts for visual percentage estimation in archaeological material. In: Middleton, A., Freestone, I. (Eds.), Recent Developments in Ceramic Petrology. British Museum Occasional Paper, 81, pp. 221-263.

Morel, J., Blanc, P., Dal Bianco, J.P., Matter, G., Pantet, A., Vuichard Pigueron, N., 2002 Chronique des fouilles archéologiques 2002. Bullettin de l'Association Pro Aventico 42, 147-171.

Peacock, D.P.S., 1982. Pottery in the Roman World: an ethnoarchaeological approach. Longman Archaeology Series. Longman, London and New York.

Richardson, H.M., Rigby, G.R., 1949. The occurrence of iron-cordierite in blast-furnace linings. Mineralogical Magazine 28, 547-556.

Rumeau, J.L., 1954. Géologie de la région de Payerne. édition Crépin-Leblond et Cie, Paris.

Sieber, R., 1959. Géologie de la région occidentale de Fribourg. Bullettin de la société fribourgeoise des sciences naturelles 48, 119-229.

Sigg, J., Maggetti, M., Galetti, G., 1986. Contribution à l'étude des terres argileuses de la région de Payerne. Bulletin de la Société Vaudois de Sciences Naturelles 78 (2), 159-193.

Tite, M.S., Kilikoglou, V., Vekinis, G., 2001. Strength, toughness and thermal shock resistance of ancient ceramics, and their influence on technological choice. Archaeometry 43, 301-324.

Young, C.J., 1977. Oxfordshire Roman pottery: the Roman pottery industry of the Oxford region. British Archaeological Reports 43. British Archaeological Reports, Oxford.

Zanco, A., 1999. Provenance and Technology of Galloroman Terra Sigillata Imitations from Western Switzerland. Unpublished PhD thesis, Institut de Minéralogie et Pétrographie, University of Fribourg. 